\title{
Possibilities of Using Module Process Designer in the Production Processes
}

\author{
Peter Trebuňa*, Radko Popovič \\ Department of Industrial engineering and management, Technical University of Košice, Faculty of Mechanical Engineering, Košice, Slovakia \\ *Corresponding author: peter.trebuna@tuke.sk
}

Received September 08, 2014; Revised September12, 2014; Accepted October 02, 2014

\begin{abstract}
By leveraging 2D/3D data and capturing and maintaining manufacturing process knowledge, Process Designer provides the means for manufacturers to develop and validate best manufacturing strategies within a 3D virtual environment. Complete line design and process modeling capabilities are available in Process Designer. Process engineers are able to model the process based on manufacturing resources that are captured in classified libraries. Required resources are dragged into the plan, and the sequence of manufacturing events can be checked for process bottlenecks and compared against actual throughput goals. Line balancing is also performed in this 3D environment by virtually aligning operations and stations to achieve an optimal production plan.
\end{abstract}

Keywords: digital factory, process designer, production processes

Cite This Article: Peter Trebuňa, and Radko Popovič, "Possibilities of Using Module Process Designer in the Production Processes.” American Journal of Mechanical Engineering, vol. 2, no. 7 (2014): 188-190. doi: 10.12691/ajme-2-7-3.

\section{Introduction}

Process Designer is a part of the software package Tecnomatix produced by Siemens company.

The main reason of usage this software is very simple. Creating new and modifying of existing processes in the manufacturing company can take a lot of time.

Nowadays, when we need to make quick decisions and changes to improve the running system, or to design the new one, it's necessary to use some tool for it.

This software can be used for planning company environment such as creation of the processes, assembly line architecture and it is very helpful for manufacturing engineers or process and facility planners.

\section{Production Process Overview}

Production process consist of many partial processes. This assembly line which is producing gearboxes consist of many assembly, press or handling processes.

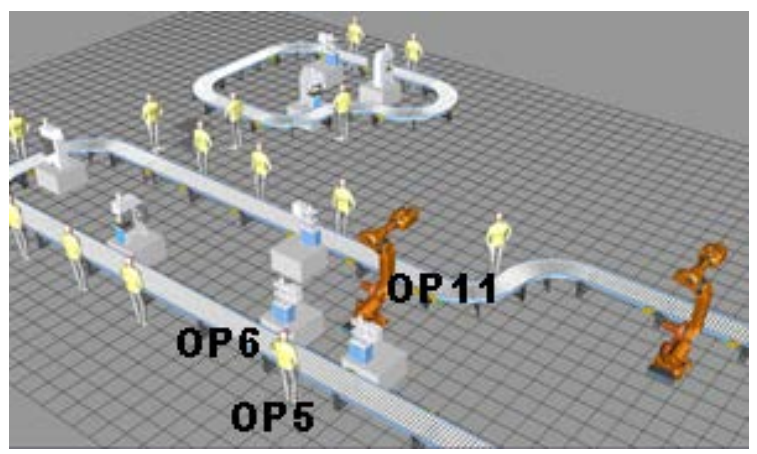

Figure 1. Operations OP5, OP6 and OP11
Based on the analysis of the selected assembly line and individual outputs with the help of software Tecnomatix Process Designer small deficiencies were found in the use of resources in the assembly line. Specifically, the workplaces OP5, OP6 and OP11 (Figure 1).

\section{Conditions before Change}

Operation OP5 of the assembly line has two partial processes.In addition to pressing plunger there is also application activities with gearbox lubrication component. This is carried out by one person on the assembly line.

After completing the lubrication the worker moves with the transmission togethernext to operation OP6, where the worker is pressing the bearings. On the opposite side there is a workplace with robot, called operation OP11.

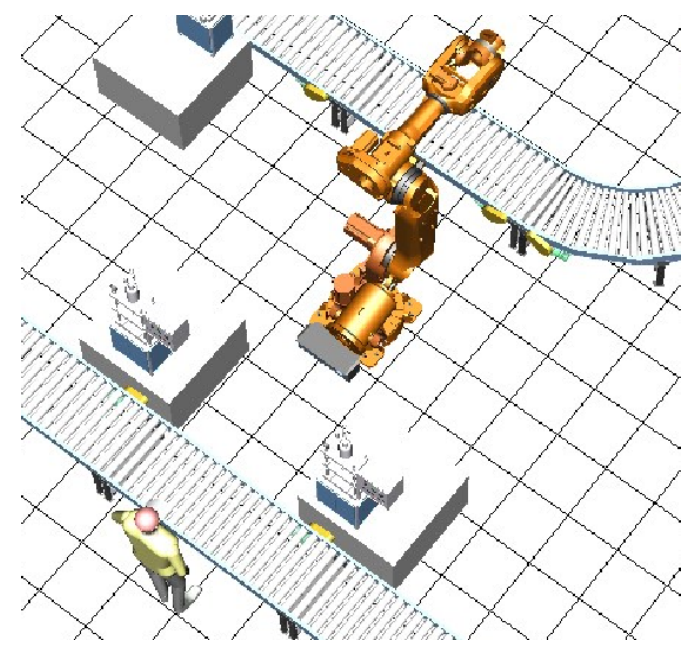

Figure 2. Detailed view on the operations OP5, OP6 and OP11 
Robot Kuka is applying seals on the gearbox. The total duration of the operations OP5 and OP6 is 31 seconds, where the gear is waiting 2 seconds for process start, the pressing component takes 14 seconds and above 15 seconds are for lubrication.

On the following picture (Figure 2) can be seen a detailed view of the optimized workplaces in the original configuration.

\section{The Proposed Changes}

Workers performed activity of lubrication gear component can be replaced by an appropriate synchronization with workplace OP11. This coating seals the operation by gear box carries KUKA robot with a time of 60 seconds. Previous operations of the OP11 is the OP10, which takes 83 seconds. From this time analyze we can see that the there is a bottlenecks on the operation OP11.

This downtime can be used for lubrication activity of gearboxcomponent. Robot's workplace OP11 has a spare time 23 seconds.

The total time required for the lubricating a gear component by robot is 7 seconds, so that's 8 seconds saved from the time of the lubrication by worker (15 seconds).

Production cycle for assembly line is 110 seconds. Itmeans, that every 110 seconds there is an assembled gearbox leaving the conveyor belt. By saving 8 seconds, the production cycle increases to 102 seconds. On the assembly line workers are working in 3 - shift operation, where one shift takes 8 hours. Before optimization the assembly line produced 785 gearboxesper day (3 shifts).

After optimization the assembly line is able to produce 847 units, that's mean an increase of 62 gearboxes. Percentage increase of production amounts to about 9\%, which is non-negligible number.

Human activity will be replaced by a robot, which is faster, more accurate and efficient and the usage of the machine will be higher than before - original configuration. With this proposal, it is necessary to check and eliminate possible downtimes or newly collisionson the other workplaces. On the following diagram (Figure 3) we can seenew Gantt chart with the shortened production time.

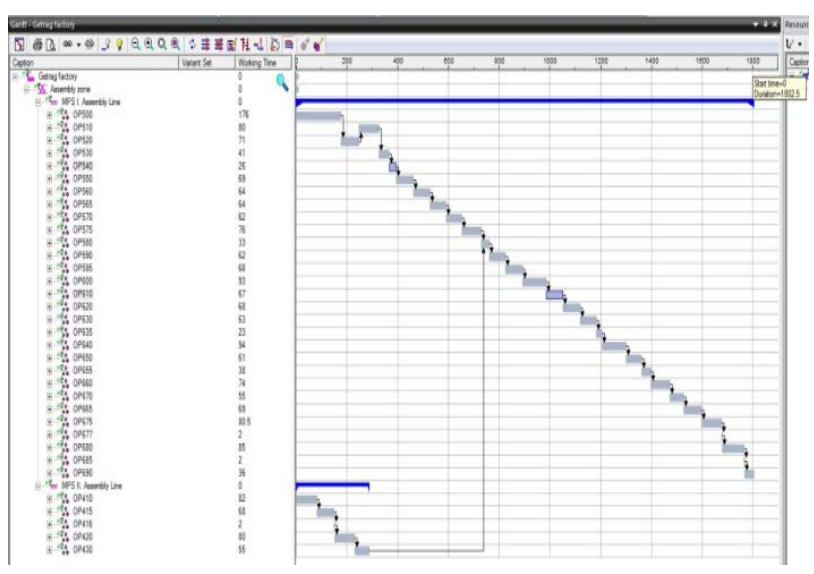

Figure 3. Time analyzes in Process Designer

Gantt chart was created in Process Designer as the function - Display Longest Path. Also there was detected a change in the total time required for one transmission. The total time was shortened from the original 1810.5 to the final 1802.5 seconds.

The advantage of this optimization is low cost of the change (implementation of improvement). The changing work there, because the operation OP540 is located in close proximity to the robot operation OP610.

However, it is necessary to reprogram the robot to carry out the addition operation, while ensuring job security robot build a relevant barriers and security sensors.

Since the company Getrag could not provide individual prices of these items and some work can procure at their own expense, it was not possible to quantify the total price for the proposed optimization.

Whole optimization can be modeled in 3D simulation of production and thus verify the applicability of the proposal in the real operation using Process Simulate module.

The following diagram (Figure 4) can be seen in a comparison of optimized display workplaces in Process Designer module (top) and Process Simulate (bottom).
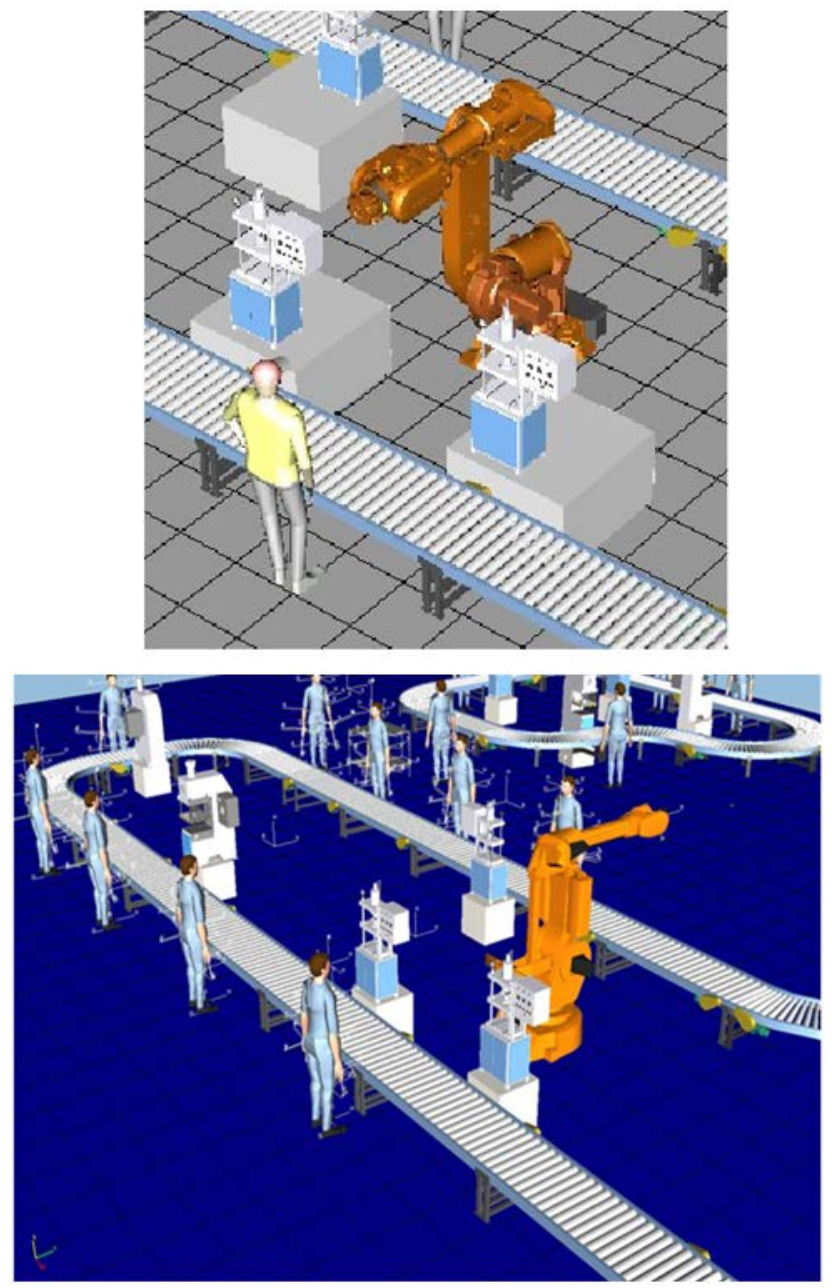

Figure 4. Optimized operations OP540 and OP610 in the module PD (up) and PS (down)

\section{Conclusion}

Process Designer facilitates the authoring and validation of manufacturing processes from concept and detailed engineering through production planning. 
Process Designer enables manufacturers to develop, capture and re-use process plans. Furthermore, process design teams can compare alternatives to develop and select best manufacturing strategies that meet specific business requirements.

In a 3D virtual environment, Process Designer is a collaborative platform that enables distributed enterprise teams to evaluate process plans and alternatives, optimize and estimate throughput and costs, plan for variants and changes and coordinate production resources.

\section{Acknowledgement}

This article was created by implementation of the grant projects KEGA 004TUKE-4/2013 Intensification of modeling in teaching II. and III. degree in the field of study 5.2.52 Industrial Engineering.

\section{References}

[1] EDL, M., LERHER, T., ROSI, B. Energy efficiency model for the mini-load automated storage and retrieval systems. International Journal of Advanced Manufacturing Technology, 2013, č. 2013, s. 1-19.

[2] KAVAN, M.: Výrobní a provozní management. Grada Publishing, Praha, 2002.

[3] BÁRDY, M., KUDRNA, J., ŠRÁMKOVÁ, B., EDL, M Interactive Game Supporting SMED Method. Applied Mechanics and Materials, 2014, roč. 474, č. 2014, s. 141-146.

[4] KUDRNA, J., MILLER, A., EDL, M. Methods of industrial engineering in network organizations. In Creating Global Competitive economies - A 360-degree Approach. Milan: International Business Information Management Association (IBIMA), 2011. s. 2037-2042.

[5] STRAKA, M., MALINDŽÁK, D.: Algoritmy kapacitného vyvažovania potlačových zariadení plánovacieho systému firmy
Alfa Folie, a.s = Algorithms of capacity balancing of printing machineries for Alfa Foils, a.s. planning system, In: Acta Montanistica Slovaca. Roč. 14, č. 1, 2009, s. 98-102.

[6] KLOS, S.: Metodyka poprawy efektywności wdrożenia systemu ERP w obszarze gospodarki materiałowej W: Inżynieria produkcji : technologia, informacja, zastosowania/ red. J. Jakubowski, S. Saniuk, R. Stryjski .- Zielona Góra : Oficyna Wydaw. Uniwersytetu Zielonogórskiego, 2007 - s. 101-112.

[7] BALOG, M., STRAKA, M.: Application of the logistics principles for the company Omega, s.r.o. in crisis time, In: Acta Logistica. Roč.1, č. 1 2014, s. 17-21.

[8] KOŠTURIAK, J., GREGOR, M.: Podnik v roce 2001 - revoluce v podnikově kultúře, Grada, Praha, 1993.

[9] SANIUK S., SANIUK A., LENORT R., SAMOLEJOVA A.: Formation and planning of virtual production networks in metallurgical clusters, in: Metalurgija, R. 53, No 4/2014, p. 725727.

[10] KLIMENT, M., TREBUŇA, P.: Prínosy softvérového portfólia TECNOMATIX, jeho moduly a súčasti využívané pri modelovaní a simulovaní podnikových procesov a ich optimalizácii. In: Transfér inovácí́. 2013, č. 25, s. 158-161. TREBUŇA P. PEKARČ́́KOVÁ M.: Supply and distribution logistics, Amos Ostrava 2013

[11] TREBUŇA P. - Fil'o, M. - PEKARČÍKOVÁ M.: Zásobovacia a distribučná logistika v príkladoch, Košice 2012.

[12] TREBUŇA, P. - KLIMENT, M. - MARKOVIČ, J.: PLM and its benefits and use in the management of complex business activities in the planning and optimization of production activities / Peter Trebuňa, Marek Kliment, Jaroslav Markovič - 2013. In: Manažment podnikov. Roč. 3, č. 2 (2013), s. 53-56.

[13] STRAKA, M., MIKUŠOVÁ, Z., LENORT, R.: Analysis and assessment of warehouse stock, In: Hutnické listy. Vol. 66, no. 3 (2013), p. 44-48.

[14] FILO, M., PEKARČÍKOVÁ, M.: Contribution to the creation of the model warehouse management in the company, In: Manažment podnikov. Roč. 3, č. 2 (2013), s. 62-64.

[15] ROSOVÁ, A., BALOG, M.: Specifikace logistických nákladů, In: Logistika v praxi. čast' 14.5.4.4. srpen (2007), 6 p.

[16] http://www.caxmix.cz/2012/07/02/tecnomatix-2-efektivniplanovani-vyrobniho-procesu/.

[17] https://www.plm.automation.siemens.com/en_gb/Images/7456_tc m642-4941.pdf. 